\title{
DIRECT OBSERVATION OF SHREW PREDATION ON INSECTS AND FISH
}

\section{by Charles H. Buckner, Department of Fisheries and Forestry, Ottawa}

Shrews are extremely secretive in their habits and detailed observations of their hehaviour under natural conditions are only rarely made. At times, however, their above-ground activity is relatively intense during daylighthours and one can observe at first hand their modes of hunting. The following observations were recorded while the author was investigating the ecology of shrews in Manitoba.

On June 27, 1958 a group of seven Cinereous Shrews, Sorex cinereus cinereus Kerr, was observed hunting resting butterflies, the Great Spangled Fritillaries, Argynnis cybele. Observations commenced at 5:30 a.m. CST and lasted about an hour. Air temperature was approximately $45^{\circ} \mathrm{F}$, skies were clear, and wind was calm. The fritillaries, obviously only recently emerged, had congregated on the mud flats of a small pond near Jessica Lake, Whiteshell Provincial Park, Manitoba, and seemed in a state of semi-torpor when first observed. Several of these butterflies were captured easily by hand by the author before a group of seven shrews, apparently two adults and five juveniles, was noticed. The juveniles were huddled under a piece of log about five inches in diameter and 18 inches long, and did not participate in the hunting. The adults were making rapid darts from the log to the place where a fritillary was resting, and then dashing back to the $\log$ with the prey. All shrews shared in the subsequent feeding. Consumption of the insects was rapid: in a matter of several seconds all that remained were the wings. When observations commenced, the shrews were reacting to prey within about 25 feet from the log under which the young shrews sheltered. However, the supply of fritillaries soon became exhausted in this small area and the hunting shrews ranged farther away. On these forays they would dart from one place of cover to another, taking advantage of $\operatorname{logs}$, sticks, leaves, stones and plants. The pattern of capture was always the same-the hunter would dash directly towards its prey from distances of approximately four feet to 20 feet from the point of cover. When the shrew reached a point roughly 18 inches from the prey, it would leap about six inches into the air and land with all feet extended on the prey insect. Occasionally the prey insect would begin to take flight, in which case the strike would be effected in the air. After being under observation by the author for approximately one hour, during which tme they were oblivious to the observer, the shrews dashed from their log shelter into the adjacent mixed wood stand. The wing remnants were gathered, and it was estimated that the two hunters had captured 134 fritillaries. The site was visited upon numerous occasions thereafter, but a repetition of these events was not observed.

On another occasion, at about $7: 30$ a.m. CST, on September 7, 1961, in a moist, grassy meadow bordering a tamarack bog near Telford, Manitoba, two subadult Saddle-backed Shrews, Sorex arcticus laricorum Jackson, were observed hunting. This time the prey insect was the grasshopper Melanoplus femur-rubrum. Again the air was cool (approximately $42^{\circ} \mathrm{F}$.), the sky clear, and the winds calm. The prey insects were observed in large numbers resting on stems of grasses and sedges. Only slight activity of the hoppers was noticed, and this was usually confined to walking slowly up the stems upon which they were resting. The shrews were observed to climb slowly up an adjacent plant about 10 inches from the intended prey. Frequently the insect would be disturbed and jump, and the shrew would then approach another insect. When the hunter was approximately 12 inches above the ground, it would jump vio- 
lently at the prey, grasping with jaws and feet. Once the strike commenced, the predator rarely missed its prey. Within about a 15-minute interval 37 strikes were observed, of which 33 were successful. The predator would rapidly consume the insect, leaving only the wings and legs. Eventually the prey insects became more mobile and began to jump away immediately they were approached. The shrews attempted only about six captures under these circumstances and then disappeared into underground runways.

I am indebted to $\mathrm{Mr}$. Glen Parsons, Conservation Officer, Manitoba Forest Service, Rennie, Manitoba, for the following account. Mr. Parsons, while on a canoe trip on the Winnipeg River, June 16, 1956, journeyed on foot at about $4: 30$ p.m. up a small stream near the Ontario boundary. The stream had numerous falls, and below each falls was a small pool, perhaps 30 feet in diameter. These pools were occupied by larger numbers of Common Shiners, Notropis cornutus fontinalis (Agassiz). Most of the minnows were about $21 / 2$ inches in length. While resting at the foot of one of these falls, $\mathrm{Mr}$. Parsons noted what appeared to be a much darker fish darting between the rocks near the turbulent area between falls and pool. Eventually the animal emerged from the water with a shiner in its mouth. This animal was clearly a Water Shrew, Sorex palustris navigator (Baird), and was observed for approximately 15 minutes. During this period, the shrew captured three shiners and consumed them on a rock at the base of the falls. The shrew would remain clinging to the shady side of a rock at the water-air interface. When a minnow approached to within about six inches, the shrew would submerge and swim quickly to its prey, attacking from below and in the belly section of the prey. The predator would then return to a rock, quickly subdue the fish, and eat parts of the head and viscera. Much of the remainder was rejected. The observer recounted that the actual strike was extremely swift and could only be observed when a close watch was made. The observer considered that the prey fish were apparently weak or injured, and that "normal" minnows were ignored.

A significant component of these observations is the evident use of vision in the diurnal hunting activities of these shrews. It is commonly believed that shrews have very poor vision and do not rely on sight for capturing prey. It would seem from these observations that the vision of shrews is more acute than has been supposed, and that it can be used in hunting. It seems unlikely in these sets of observations that any other sense was involved in locating and reacting to the prey.

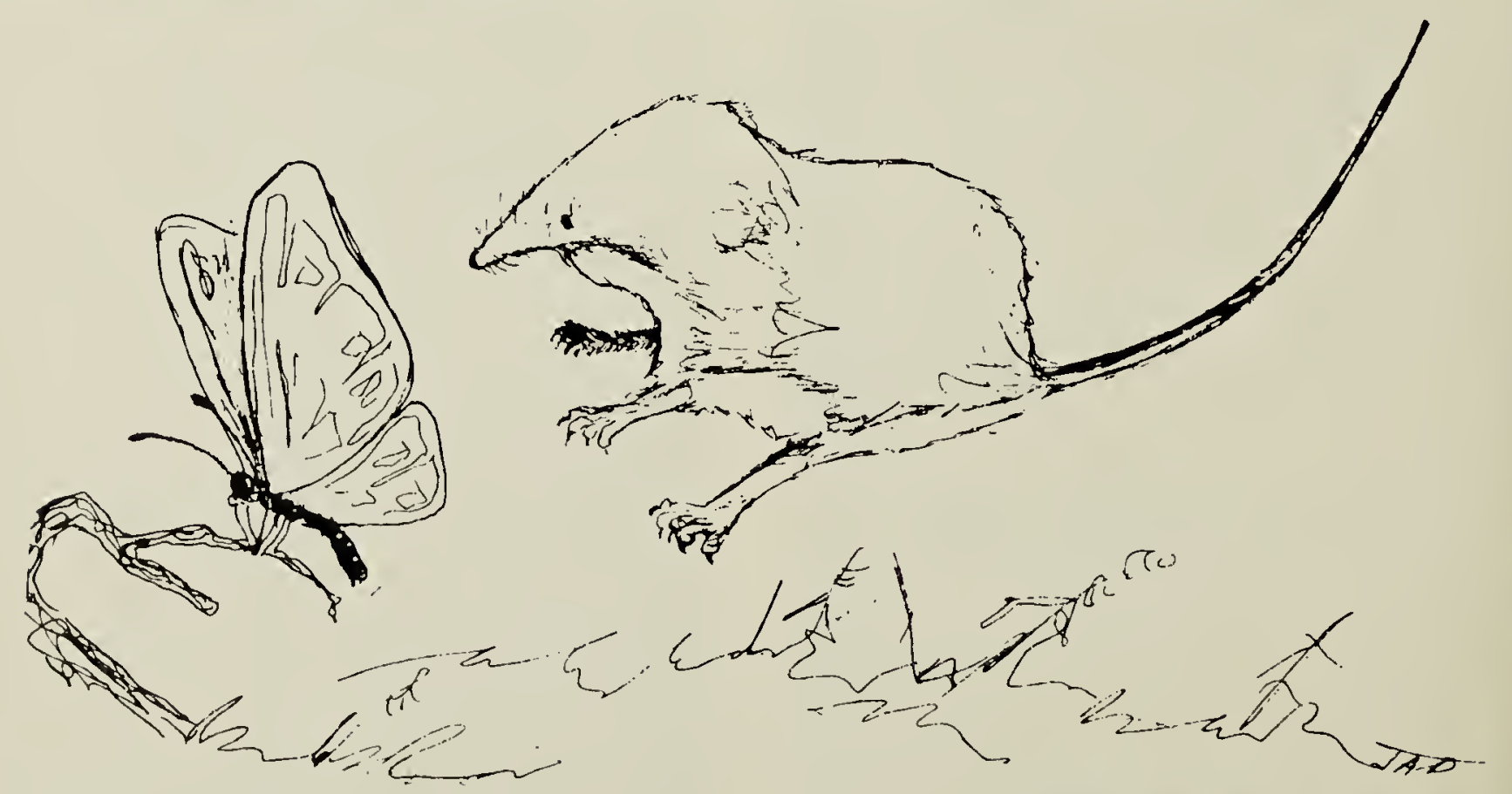

Shrew attacking butterfly

Drawing by J. A. Drovin 